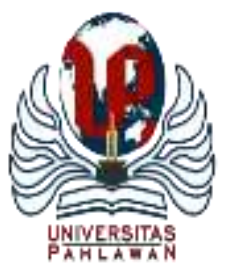

Edukatif : Jurnal Ilmu Pendidikan Volume 4 Nomor 1 Tahun 2022 Halm 1083 - 1093

EDUKATIF: JURNAL ILMU PENDIDIKAN

Research \& Learning in Education

https://edukatif.org/index.php/edukatif/index

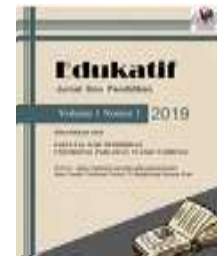

\title{
Implementasi Model Pembelajaran Inkuiri Terbimbing Berbasis Google Classroom Terhadap Keterampilan Proses Sains Peserta Didik pada Materi Kesetimbangan Kimia
}

\author{
Nurul Hikmatun Uliya ${ }^{1 凶}$, Muchlis $^{2}$ \\ Universitas Negeri Surabaya, Indonesia ${ }^{1,2}$ \\ E-mail : $\underline{\text { nurululya509@ gmail.com }}^{1},{\underline{\text { muchlis@ } \text { unesa.ac.id }^{2}}}^{2}$
}

\begin{abstract}
Abstrak
Penelitian ini digunakan untuk mengetahui pelaksanaan model pembelajaran inkuiri terbimbing berbasis google classroom, aktivitas peserta didik dan pemenuhan hasil belajar Keterampilan Proses Sains peserta didik pada materi kesetimbangan kimia. Metode yang dipakai pada riset ini ialah one grup pretest-posttest design dengan sampel 34 peserta didik kelas XI MIPA 1 MA Negeri Pacitan. Hasil yang didapat dari riset ini adalah keterlaksanaan pendidikan inkuiri terbimbing mendapatkan kategori sangat layak dengan rata-rata keterlaksanaan $95 \%$ didukung pula dengan waktu efektivitas penggunaan google classroom dalam pembelajaran inkuiri terbimbing sebanyak 45 menit dalam pertemuan pertama serta 43 menit pada pertemuan kedua. Selain itu, terdapat ketuntasan hasil belajar keterampilan proses sains dengan model inkuiri terbimbing berbasis google classroom memperoleh nilai $\geq 70$ dengan ketuntasan klasikal yang sudah melebihi $75 \%$ yaitu $82,35 \%$ dan angka $\mathrm{N}$-gain untuk 26 peserta didik mencapai katergori tinggi dan 5 peserta didik mencapai kategori sedang.
\end{abstract}

Kata Kunci: google classroom, inkuiri terbimbing, peserta didik, pembelajaran

Abstract

The study aims to determine the implementation of the guided inquiry learning model based on google classroom, student activities, and the completeness of participants' learning outcomes of Science Process Skills on chemical equilibrium material. The method used in this study is a one-group pretest-posttest design with a sample of 34 students in class XI MIPA 1 Madrasah Aliyah Negeri Pacitan. The results obtained from this study are the implementation of guided inquiry learning is in a very feasible category with an average implementation of $95 \%$ supported also by the effectiveness time of using google classroom in guided inquiry learning as much as 45 minutes at the first meeting and 43 minutes at the second meeting. In addition, there is completeness in learning outcomes of science process skills with a guided inquiry model based on google classroom, obtaining a score of 70 with classical completeness that has exceeded $75 \%$, namely $82.35 \%$ and $\mathrm{N}$-gain scores for 26 students reaching the high category and 5 students reach the low category.

Keywords: google classroom, guided inquiry learning, student, chemical equilibrium.

Copyright (c) 2022 Nurul Hikmatun Uliya, Muchlis

$\triangle$ Corresponding author:

Email : nurululya509@gmail.com

DOI : https://doi.org/10.31004/edukatif.v4i1.2134

ISSN 2656-8063 (Media Cetak)

ISSN 2656-8071 (Media Online)

Edukatif : Jurnal Ilmu Pendidikan Vol 4 No 1 Tahun 2022

p-ISSN 2656-8063 e-ISSN 2656-8071 
1084 Implementasi Model Pembelajaran Inkuiri Terbimbing Berbasis Google Classroom Terhadap Keterampilan Proses Sains Peserta Didik pada Materi Kesetimbangan Kimia - Nurul Hikmatun Uliya, Muchlis

DOI: https://doi.org/10.31004/edukatif.v4i1.2134

\section{PENDAHULUAN}

Mata pelajaran wajib yang dipelajari di jenjang SMA IPA salah satunya adalah kimia. Di dalam mata pelajaran kimia banyak sekali ilmu-ilmu tentang pengolahan bahan alam, cara-cara kimiawi tentang proses yang ada di alam yang dapat membuat pengembangan cara berpikir peserta didik. Belajar kimia bertujuan untuk dapat memahami lebih banyak hal gejala dan proses yang berada di alam dan kehidpuan sehari-hari yang berlangsung secara kimia. Disamping itu, mata pelajaran kimia dapat dijadikan sebagai pengetahuan awal untuk mengelola bahan-bahan yang ada di alam menjadi suatu produk yang bermanfaat (Hariandja, 2009). Mata pelajaran kimia dimaksudkan buat meningkatkan keahlian asumsi peserta didik sehingga keterampilan proses sains pada kehidupan setiap hari dapat terealisasikan melalui pelajaran kimia (Mahdian et al., 2019).

Permasalahan yang terjadi saat mempelajari mata pelajaran kimia di SMA cukup sulit dikarenakan materi yang cukup kompleks dan rumit. Banyak reaksi-reaksi kimia yang belum pernah dipelajari dijenjang sebelumnya. Rumus yang sangat banyak juga menyulitkan peserta didik ketika akan memahami materi kimia, terlebih lagi konsep yang abstrak dianggap penyebab utama sulitnya memahami materi kimia oleh peserta didik (Ristiyani \& Bahriah, 2016). Bersumber pada pra-penelitian yang dicoba pada bertepatan pada 23 November 2021 di kelas XI MIPA 1 MA Negeri Pacitan yang berjumlah 34 orang, 79,41\% peserta didik mengatakan bahwa belajar kimia merupakan pelajaran yang sulit. Hal ini membuktikan jika keterampilan berpikir peserta didik dalam materi kimia masih belum maksimal.

Penelitian di SMA Negeri 10 Malang tahun ajaran 2014/2015 di kelas XI MIA 1 serta XI MIA 3 yang berjumlah 72 peserta didik diberikan 26 soal pilihan ganda tentang materi kesetimbangan kimia. Terdapat 3 konsep soal yang diberikan yaitu kesetimbangan dinamis, konstanta keseimbangan serta faktor- faktor yang pengaruhi keseimbangan kimia, Sebanyak $61 \%$ peserta didik menjawab dengan salah pada sub materi kesetimbangan dinamis, 39\% salah menjawab pada sub materi konstanta kesetimban dan 30\% salah menjawab pada sub materi fakotr-faktor yang mempengaruhi kesetimbangan. Sub materi kesetimbangan dinamis dapat dibilang mendapat kategori yang cukup tinggi kesulitan yang dialami oleh peserta didik. Perihal ini dikarenakan mayoritas peserta didik yang beranggapan bahwa saat keadaan setimbang, reaksi yang terjadi telah berhenti dan konsentrasi produk dianggap sama dengan konsentrasi reaktan (Indriani et al., 2017). Penelitian yang terdapat di kota Palangka Raya yang dilakukan di lima sekolah yaitu SMAN 1 Palangka Raya, SMAN 2 Palangka Raya, SMAN 3 Palangkaraya, SMAN 4 Palangkaraya dan SMAN 5 Palangkaraya diujikan ke 928 peserta didik. Terdapat 10 butir soal dan 5 indikator soal yaitu menarangkan akibat pergantian Konsentrasi kepada perpindahan keseimbangan kimia didapatkan $62,82 \%$ peserta didik kesulitan dalam menjawab soal, menarangkan akibat pergantian temperatur pada saat perpindahan keseimbangan kimia sebanyak 55,28\% peserta didik kesulitan menjawab soal, menarangkan akibat pergantian pengaruh volume kepada perpindahan balans kimia sebanyak $61,96 \%$ peserta didik kesulitan menjawab soal, menarangkan akibat pergantian titik berat pada perpindahan balans kimia sebanyak 53,56\% peserta didik kesulitan menjawab soal dan menarangkan prinsip respon keseimbangan dalam pabrik didapatkan $66,06 \%$ kesulitan menjawab soal. Hal ini membuktikan jika masih terdapat peserta didik yang kesulitan memhami pada materi kesetimbangan kimia (Seliwati et al., 2020).

Materi kesetimbangan kimia menjelaskan reaksi reversibel dan irreversibel, maksudnya adalah keadaan suatu proses dengan timbal balik yang sama. Keadaan reversibel adalah keadaan yang dapat dikembalikan ke keadaan awal sebelum berubah menjadi proses yang berbeda, sedangkan irreversibel adalah keadaan suatu proses sebelum proses tersebut mengalami suatu perubahan tidak dapat berubah kembali. Secara ilmiah, kesetimbangan kimia dapat diartikan sebagai kondisi laju respon maju serta respon balik dari sesuatu zat dalam jumlah yang sama, serta kandungan zat yang bereaksi tidak dapat berubah dengan produk seiring waktu 
1085 Implementasi Model Pembelajaran Inkuiri Terbimbing Berbasis Google Classroom Terhadap Keterampilan Proses Sains Peserta Didik pada Materi Kesetimbangan Kimia - Nurul Hikmatun Uliya, Muchlis

DOI: https://doi.org/10.31004/edukatif.v4i1.2134

berjalan. Perubahan pada kondisi seimbang dalam sesuatu respon terletak pada tingkatan molekuler hasilnya tidak mudah untuk dilihat dengan mata terbuka atau biasa disebut mikroskopis. Oleh karena itu, penggambaran alur terhadap perubahan yang terjadi dibutuhkan pemikiran yang cukup luas untuk menggambarkan bagaimana proses-proses tersebut bisa terjadi (Dewi, 2009).

Keterampilan proses sains sangat penting untuk dikembangkan sebagai sarana mengatasi permasalah pada kesulitan memahami suatu materi khususnya pada materi kimia. Pada keterampilan ini peserta didik akan dituntut untuk bagaimana caranya mendapatkan pengetahuan yang baru dari pengetahuan awal yang telah didapatkan oleh meraka sebelumnya. Peserta didik juga dituntuk untuk aktif dan kreatif dalam keterampilan ini untuk mendapatkan informasi-informasi penting dari suatu pembelajaran (Nurliani et al., 2018). Materi yang cukup kompleks seperti kesetimbangan kimia sangat cocok untuk diterapkannya keterampilan proses sains ke dalam pembelajarannya supaya dapat membantu memahami proses berpikir peserta didik.

Secara teoritis, keterampilan proses sains merupakan pendekatan kepada peserta didik untuk menciptakan fakta- fakta, membuat rancangan, serta teori dalam pendidikan yang didapatkan. Keterampilan proses sains dimaksudkan untuk faham tentang fenomena ilmiah yang terdapat pada kehidupan setiap hari. Keterampilan proses sains juga dirancang untuk mendapatkan, meningkatkan serta mempraktikkan prinsipprinsip serta hukum sains (Amnie et al., 2014). Keterampilan ini diajarkan untuk merumuskan permasalahan, membuat hipotesis, mengenali variabel, mengakulasi informasi, serta membuat kesimpulan. Dalam keahlian cara sains, merumuskan konflik serta membuat hipotesis yaitu langkah awal yang sangat signifikan untuk membentuk keterampilan sains (Diara et al., 2017).

Penelitian di SMAN Ngoro Jombang pada kelas XI MIPA 2 berjumlahkan 34 peserta didik membuktikan kalau keahlian proses sains terbilang cukup rendah. Hasil pretest pada ranah pengetahuan keterampilan proses sains didapatkan pada aspek merumuskan masalah mendapatkan rata-rata nilai 65,44 , pada aspek merumuskan masalah mendapat rata-rata nilai 50,00, aspek mengidentifikasi variabel mendapat rata-rata nilai 27,21, pada menganalisis data mendapatkan rata-rata nilai paling rendah yaitu 13,97 dan nilai 27,21 untuk aspek membuat kesimpulan (Hidayati \& Yonata, 2019). Pada penelitian di SMAN 1 Karanganyar kelas XI MIPA 9 menunjukkan bahwa keterampilan proses masih tergolong cukup rendah dengan rata-rata nilai 31,41. Terdapat banyak aspek yang difokuskan di dalam penelitian itu dan semua nilai yang di dapat masih di bawah nilai 40. Tiga aspek yang mendapatkan nilai terendah adalah merencanakan percobaan dengan nilai 29,43, menerapkan konsep dengan nilai 27,82 dan terendah adalah aspek mempredeksi dengan nilai 27,01 (Rahmasiwi et al., 2015).

Inkuiri terbimbing merupakan pendekatan yang menuntut peserta didik untuk aktif menyelidiki, mencari masalah, dan memaksa berfikir aktif. Pendekatan inkuiri terbimbing memberi lebih banyak peluang kepada peserta didik untuk mendapatkan fakta, kerangka serta prinsip lewat pengalaman mereka sendiri (Mulyana et al., 2018). Hal ini sangat cocok untuk mengembangkan kreativitas proses sains yang dipunyai oleh peserta didik. Inkuiri terbimbing mempunyai 5 tahapan yang harus diterapkan, pada tahap pertama peserta didik diharapkan untuk merumuskan sebuah masalah yang sesuai dengan sub bab ketika pembelajaran saat itu Pada tahap kedua peserta didik dapat mengumpulkan data terkait konflik yang sudah dirumuskan pada tahap pertama. Setelah itu, tahap ketiga peserta didik mencari tentang data eksperimen yang selaras melalui konflik yang sudah dirumuskan. Pada tahap keempat, peserta didik dapat merumuskan dan menjawab masalah yang telah ditanyakan sehingga akan terpapar jawaban yang relevan dari sebuah sumber. Serta tahap kelima peserta didik dan guru dapat menganlisis proses inkuiri yang terjadi (Hidayati \& Yonata, 2019). Singkatnya, tugas guru hanya sebagai fasilisator dan pemancing agar peserta didik melakukan sesuatu. Guru membimbing dan memberi petunjuk ke peserta didik untuk memancing peserta didik untuk berpikir secara ilmiah serta tidak keluar jalur yang semestinya. Sarana lembar kerja peserta didik (LKPD) disediakan oleh guru untuk peserta didik yang di dalamnya ada pertanyaan-pertanyaan dan masalah, yang kemudian akan dijawab oleh peserta 
1086 Implementasi Model Pembelajaran Inkuiri Terbimbing Berbasis Google Classroom Terhadap Keterampilan Proses Sains Peserta Didik pada Materi Kesetimbangan Kimia - Nurul Hikmatun Uliya, Muchlis

DOI: https://doi.org/10.31004/edukatif.v4i1.2134

didik dengan bimbingan dari guru (Ambarsari et al., 2013). Berdasarkan hasil pra-penelitian di MA Negeri Pacitan, metode yang paling sering digunakan untuk mengajar yaitu ceramah sebanyak 70,59\% diikuti dengan presentasi 17,64\% dan diskusi 14,71\%. Melalui inkuiri terbimbing, peserta didik akan diarahkan berpikir lebih aktif daripada hanya mendengarkan penjelasan dari guru.

Tahun 2019 kementrian pendidikan serta kebudayaan mengeluarkan surat putusan bahwasannya sekolah dilakukan dari rumah tiap-tiap ataupun lazim diucap dengan daring (dalam jaringan) dikarenakan pandemi covid-19 yang sudah meluad di semua bumi salah satunya Indonesia, guna mencegah menyebarnya wabah tersebut maka dilakukan pembelajaran dari rumah. Oleh karena itu, terdapat kesulitan belajar peserta didik yang biasanya dilakukan di dalam sekolah menjadi di sekolah masing-masing (Nafsi \& Trisnawati, 2022). Pada masa perkembangan teknologi saat ini sangat cocok untuk diterapkannya aplikasi-aplikasi belajar yang dapat memudahkan untuk peserta didik belajar.Salah satu inovasi dalam bentuk pendidikan berplatform teknologi data antara lain merupakan animation learning, games learning, tutorial computer based learning (Hammi, 2017). Tidak hanya hal positif saja yang terjadi pada perkembangan teknologi, dampak yang cukup mengkawatirkan dapat terjadi diantaranya seperti kerusakan lingkungan. Maka dari itu sebagai guru bisa membimbing agar peserta didik bisa menggunakan media digital dengan baik terutama pada masa pandemi yang entah sampai kapan selesainya (Rakim et al., 2017).

Salah satu solusi untuk masa pandemi yang terjadi sekarang ini adalah e-learning. E-learning yaitu sebuah sistem yang digunakan untuk pembelajaran dengan memanfaatkan media digital atau singkatnya pembelajaran secara online (Pendy et al., 2022). Salah satu aplikasi yang bisa dipakai buat pembelajaran yaitu google classroom. Google classroom di desain dengan simpel dan lengkap agar memudahkan penggunaannya. Google classroom merupakan suatu aplikasi dari suatu web yang di dalamnya dapat menciptakan sebuah kelas, diskusi, membuat tugas, dan juga menilai tugas yang telah dikumpulkan. Aplikasi ini bisa dimafaatkan untuk mempermudah pembelajaran ketika waktu guru tidak masuk kelas, karena peserta didik atau guru bisa melakukan pendidikan di mana saja serta dapat sewaktu-waktu hanya dengan sebuah handphone atau personal computer tidak seperti di sekolah-sekolah pada umumnya (Sabran \& Sabara, 2019).

Google classroom memudahkan peserta didik serta guru untuk waktu yang akan digunakan sebagai pendidikan. Guru bisa memberikan pembelajaran dan tugas kepada peserta didik sewaktu-waktu sesuai kesepakatan kedua belah pihak Selain itu, guru dan peserta didik dalam melakukan diskusi dengan ruang diskusi yang telah disediakan oleh google classroom ketika ada pelajaran yang belum paham atau dapat digunakan juga sebagai pembelajaran pada umumnya. Google telah menjamin keamanan yang cukup tinggi pada aplikasi google classroom. Pada aplikasi ini, kita dapat masuk menggunakan akun gmail yang merupakan produk google yang dikenal mempunyai keamanan yang sangat tinggi sesuai prosedur yang ada (Atikah et al., 2021). Disamping keuntungan yang melimpah dari google classroom, syarat penting yang harus dipenuhi ketika menggunakan aplikasi ini adalah koneksi internet yang cukup mumpuni agar pembelajaran tetap terjaga dengan lancar. Aplikasi ini bisa dipakai oleh siapapun yang telah mendapatkan undangan atau kode dari admin atau dapat dikatakan untuk pendidikan yaitu dari guru. Guru dapat mendesain sedemikian rupa dan prosedur yang ada mirip seperti pembelajaran yang dilakukan pada umumnya. Guru juga harus memperhatikan ketika membuat sebuah kelas, kelas harus dinamai sesuai mata pelajaran dan kelas yang akan diajar agar tidak terdapat kesalahan ketika masuk ruang kelas (Hammi, 2017).

Sesuai dengan latar belakang yang sudah dipaparkan pada penelitian ini, maka diterapkannya model pembelajaran inkuiri terbimbing berbasis google classroom buat melatihkan keahlian cara ilmu pada modul kesetimbangan kimia kelas XI IPA MA Negeri Pacitan. Dengan memakai kreativitas proses sains serta aplikasi google classroom, diharapkan peserta didik bisa mendapatkan rancangan dengan bagus alhasil hasil berlatih peserta didik bisa menemui kata maksimal serta dapat memaksimalkan kemajuan teknologi yang sedang kita alami di masa sekarang ini 
1087 Implementasi Model Pembelajaran Inkuiri Terbimbing Berbasis Google Classroom Terhadap Keterampilan Proses Sains Peserta Didik pada Materi Kesetimbangan Kimia - Nurul Hikmatun Uliya, Muchlis

DOI: https://doi.org/10.31004/edukatif.v4i1.2134

\section{METODE PENELITIAN}

Penelitian ini mempunyai tujuan untuk mengembangkan keterampilan proses sains peserta didik memakai metode inkuri terbimbing berbasis google classroom pada materi kesetimbangan kimia. Cara yang dipakai untuk riset ini yaitu one-grup pretest-posttest design ialah diberikan pretest di awal pembelajaran dimulai sebelum diterapkan inkuiri terbimbing untuk mengetahui konsep awal peserta didik serta diberikan posttest setelah diterapkannya inkuiri termbimbing untuk melihat ketuntasan hasil belajar keterampilan proses sais peserta didik. Maka akan diketahui pengaruh hasil dari model inkuiri terbimbing berbasis google classroom. Riset ini dilakukan di kelas XI IPA MA Negeri Pacitan.

Silabus, RPP (Rancangan Pelaksanaan Pembelajaran), LKPD (Lembar Kerja Peserta Didik) berbasis google classroom termasuk perangkat pembelajaran yang dipakai pada riset ini. Riset ini memakai instrumen diantaranya adalah lembar observasi pelaksanaan pembelajaran, lembar observasi aktivitas peserta didik, lembar pretest dan postest kreativitas proses sains, serta lembar respon peserta didik. Metode pengumpulan data pada riset ini didasarkan pada metode tes untuk mengetahui kelulusan hasil belajar keterampilan proses sains peserta didik.

Keterlaksanaan proses model inkuiri terbimbing diamati oleh seorang pengamat secara berkala pada google classroom. Pengamat mengamati model pembelajaran inkuiri terbimbing dengan masuk didalam kelas yang akan diuji. Hal yang tidak jauh berbeda dengan observasi kelas secara langsung, pengamat akan mengamati beberapa aspek-aspek penting ketika masuk di dalam google classroom. Hasil dari pengamatan akan dikonversikan ke dalam skor 0-4 yang didapatkan dari skala Likert yang tertera pada Tabel 1.

\section{Tabel 1}

Skala Likert

\begin{tabular}{ccc}
\hline No & Penilaian & Nilai Skala \\
\hline 1 & Tidak Baik & 1 \\
2 & Kurang Baik & 2 \\
3 & Cukup & 3 \\
4 & Baik & 4 \\
5 & Sangat Baik & 5 \\
\hline
\end{tabular}

Perhhitungan presentase keterlaksanaan hasil pengamatan skala Likert dapat dihitung menggunakan rumus:

$$
P \%=\frac{\text { Jumlah Skor }}{\text { Skor Kriteria }} \times 100 \%
$$

Perhitungan presentase keterlaksanaan hasil pengamatan skala Likert menggunakan rumus sebagai berikut:

Tabel 2

Interpretasi Skor Skala Likert

\begin{tabular}{ccc}
\hline No & Penilaian & Kriteria Interpretasi Skor \\
\hline 1 & $0 \%-20 \%$ & Tidak Layak \\
2 & $21 \%-40 \%$ & Kurang Layak \\
3 & $41 \%-60 \%$ & Cukup Layak \\
4 & $61 \%-80 \%$ & Layak \\
5 & $81 \%-100 \%$ & Sangat Layak \\
\hline
\end{tabular}

(Riduwan, 2015)

Keterlaksanaan model pembelajaran inkuiri terbimbing dapat dikatakan layak apabila persentase skor keterlaksanaan sebesar $\geq 61 \%$ dengan kategori layak atau sangat layak. 
1088 Implementasi Model Pembelajaran Inkuiri Terbimbing Berbasis Google Classroom Terhadap Keterampilan Proses Sains Peserta Didik pada Materi Kesetimbangan Kimia - Nurul Hikmatun Uliya, Muchlis

DOI: https://doi.org/10.31004/edukatif.v4i1.2134

Aktivitas yang dikerjakan peserta didik diamati oleh 1 pengamat, aktivitas peserta didik dikatakan mendukung proses pembelajaran dalam melatihkan keterampilan proses sains apabila besarnya persentase aktivitas yang relevan akan lebih besar jika dibandingkan dengan persentase aktivitas yang tidak relevan. Aktivitas tersebut dianalisis dengan menggunakan rumus:

$$
\% \text { aktivitas peserta didik }=\frac{\sum \text { frekuensi aktivitas yang muncul }}{\sum \text { frekuensi aktivitas keseluruhan }} \times 100 \%
$$

Rumus yang digunakan untuk menghitung hasil skor pretest dan posttest dalam menentukan ketuntasan belajar peserta didik dapat dilihat berikut ini:

$$
K B=\frac{T}{T t} \times 100 \%
$$

Keterangan:

$\mathrm{KB}=$ ketuntasan belajar

$\mathrm{T} \quad=$ jumlah skor yang diperoleh peserta didik

$\mathrm{Tt}=$ jumlah skor total

Persamaan N-gain score dapat digunakan untuk menghitung ketrampilan proses sains sebelum diterapkan dan sesudah diterapkannya model pembelajaran inkuiri terbimbing. Rumus yang digunakan dapat dilihat berikut ini:

$$
<g>=\frac{\%(S f)-\%(S i)}{100-\%(S i)}
$$

Keterangan:

$$
\begin{aligned}
& \langle\mathrm{g}\rangle=N \text {-gain score } \\
& \mathrm{Sf}=\text { skor posttest } \\
& \mathrm{Si}=\text { skor pretest }
\end{aligned}
$$

Kriteria tingkat $\mathrm{N}$-gain score ditunjukkan pada tabel 3.

Tabel 3

Kriteria Tingkat $N$-gain Score

\begin{tabular}{cc}
\hline Skor & Skor \\
\hline $\mathrm{g} \geq 0,7$ & Tinggi \\
$0,3 \geq \mathrm{g}<0,7$ & Sedang \\
$\mathrm{g}<0,3$ & Rendah \\
\hline & (Meltzer, 2002)
\end{tabular}

Pembelajaran inkuiri terbimbing berbasis google classroom dapat dikatakan efektif jika tingkat $\mathrm{N}$-gain score mencapai sedang atau tinggi.

Ketuntasan indvidual peserta didik dikatakan tuntas belajarnya apabila nilai dari setiap peserta didik mencapai nilai minimal KKM atau dapat dipresentasekan $\geq 70 \%$. Lain hal dengan ketuntasan suatu kelas atau biasa disebut dengan ketuntasan klasikal, suatu kelas akan dikatakan tuntas belajarnya apabila $\geq 75 \%$ memperoleh nilai minimal sama dengan KKM atau dalam penelitian ini setidaknya memperoleh nilai $\geq 70$ dan nilai N-gain dalam satu kelas dapat mencapai kateogri tinggi dan sedang.

\section{HASIL DAN PEMBAHASAN PENELITIAN}

\section{Keterlaksanaan Model Inkuiri Terbimbing}

Penelitian terhadap model pembelajaran inkuiri terbimbing berbasis google classroom dilakukan sebanyak dua kali pertemuan yaitu tanggal 26 dan 29 November 2021 di MA Negeri Pacitan yang diamati satu mahasiswa jurusan kimia FMIPA Unesa. 
1089 Implementasi Model Pembelajaran Inkuiri Terbimbing Berbasis Google Classroom Terhadap Keterampilan Proses Sains Peserta Didik pada Materi Kesetimbangan Kimia - Nurul Hikmatun Uliya, Muchlis

DOI: https://doi.org/10.31004/edukatif.v4i1.2134

Terdapat tahapan-tahapan yang akan dilakukan pada penelitian ini. Kegiatan pendahuluan yang dilakukan adalah peserta didik mengakses google classroom dan absen pada kolom komentar serta guru sambil mengecek kehadiran peserta didik. Guru juga menyampaikan apresepsi, motivasi dan tujuan pembelajaran selama dua pertemuan sebagai bentuk informasi baru yang dapat dikaitkan dengan pengetahuan awal peserta didik.

Lewat kolom komentar pada google classroom terdapat interaksi peserta didik dengan guru ketika memberikan penjelasan, Teknis ketika menjawab pada kolom komentar, peserta didik diwajibkan menuliskan nama dan nomor absen terlebih dahulu.

Langkah selanjutnya, guru memberikan LKPD yang sudah diunggah pada google classroom. Guru membimbing peserta didik dalam menganalisis fenomena yang ada di dalam LKPD serta menjawab pertanyaan-pertanyaan dan menuliskannya pada kolom komentar.

Kemudian, guru membimbing peserta didik dalam menganalisis video percobaan yang terdapat pada link yang tertera di dalam LKPD. Video tersebut dianalisa dan didiskusikan di kolom komentar google classroom. Lalu, peserta didik menyusun hipotesis bersama guru serta menyusun kesimpulan dalam komentar google classroom. Seluruh sintak model pembelajaran inkuiri terbimbing berbasis google classroom mendapatkan kategori sangat layak dengan rata-rata keterlaksanaan $95 \%$.

Tabel 4

Hasil Keterlaksanaan Kegiatan Pembelajaran Model Pembelajaran Inkuiri Terbimbing

\begin{tabular}{|c|c|c|c|c|c|c|}
\hline \multirow[b]{2}{*}{$\begin{array}{c}\text { Kegiatan } \\
\text { Pembelajaran }\end{array}$} & \multicolumn{3}{|c|}{ Pertemuan ke-1 } & \multicolumn{3}{|c|}{ Pertemuan ke-2 } \\
\hline & $\begin{array}{c}\text { Skor } \\
\text { rata- } \\
\text { rata }\end{array}$ & $\begin{array}{c}\text { Rata-rata \% } \\
\text { keterlaksanaan }\end{array}$ & Kategori & $\begin{array}{c}\text { Skor } \\
\text { Rata- } \\
\text { rata }\end{array}$ & $\begin{array}{c}\text { Rata-rata \% } \\
\text { keterlaksanaan }\end{array}$ & Kategori \\
\hline Pendahuluan & 4 & 100 & Sangat Layak & 3,8 & 95 & Sangat Layak \\
\hline fase 1 & 3,6 & 90 & Sangat Layak & 4 & 100 & Sangat Layak \\
\hline fase 2 & 3,8 & 95 & Sangat Layak & 3,6 & 90 & Sangat Layak \\
\hline fase 3 & 4 & 100 & Sangat Layak & 3,8 & 95 & Sangat Layak \\
\hline fase 4 & 3,8 & 95 & Sangat Layak & 3,6 & 90 & Sangat Layak \\
\hline fase 5 & 3,6 & 90 & Sangat Layak & 3,8 & 95 & Sangat Layak \\
\hline penutup & 4 & 100 & Sangat Layak & 4 & 100 & Sangat Layak \\
\hline
\end{tabular}

Aktivitas Peserta Didik

Aktivitas peserta didik diamati oleh seroang pengamat dengan menggunakan lembar pengamatan aktvitas peserta didik. Hal ini ditujukan untuk mengamati sebera efektif waktu yang digunakan ketikan pembelajaran model inkuiri terbimbing di dalam google classroom.

\section{Tabel 5}

Waktu Aktivitas Peserta Didik

\begin{tabular}{clcc}
\hline No & \multicolumn{1}{c}{ Aktivitas Peserta Didik } & \multicolumn{2}{c}{ Waktu Aktivitas } \\
\cline { 3 - 4 } & \multicolumn{1}{c}{ Pertemuan 1 } & Pertemuan 2 \\
\hline 1 & $\begin{array}{l}\text { Peserta didik mengakses Google Classroom dan absen pada } \\
\text { kolom komentar } \\
2\end{array}$ & $\begin{array}{l}\text { Memeriksa kehadiran peserta didik sebagai sikap disiplin } \\
\text { melalui google classroom }\end{array}$ & 5 \\
3 & $\begin{array}{l}\text { Aktif memberi tanggapan ketika guru memberi penjelasan } \\
\text { pada kolom komentar google classroom }\end{array}$ & 7 & 2 \\
4 & $\begin{array}{l}\text { Peserta didik menuliskan nama dan nomor absen ketika akan } \\
\text { menjawab pertanyaan }\end{array}$ & 15 & 14 \\
5 & $\begin{array}{l}\text { Peserta didik membetulkan jawabaan teman yang salah } \\
\text { Menganalisis fenomena yang ada dalam LKPD dengan } \\
\text { menjawab pertanyaan pada LKPD dan menulis pada kolom }\end{array}$ & 25 & 17 \\
\end{tabular}


1090 Implementasi Model Pembelajaran Inkuiri Terbimbing Berbasis Google Classroom Terhadap Keterampilan Proses Sains Peserta Didik pada Materi Kesetimbangan Kimia - Nurul Hikmatun Uliya, Muchlis

DOI: https://doi.org/10.31004/edukatif.v4i1.2134

\begin{tabular}{|c|c|c|c|}
\hline \multirow{2}{*}{ No } & \multirow{2}{*}{ Aktivitas Peserta Didik } & \multicolumn{2}{|c|}{ Waktu Aktivitas } \\
\hline & & Pertemuan 1 & Pertemuan 2 \\
\hline & komentar google classroom & & \\
\hline 7 & $\begin{array}{l}\text { Bertanya kepada guru ketika kurang jelas di kolom komentar } \\
\text { pada google classroom }\end{array}$ & 31 & 25 \\
\hline 8 & $\begin{array}{l}\text { Menganalisis video percobaan dengan menjawab pertanyaan } \\
\text { pada LKPD dan menuliskan di kolom komentar google } \\
\text { classroom }\end{array}$ & 33 & 25 \\
\hline 9 & $\begin{array}{l}\text { Saling berdiskusi dikolom komentar terkait video dan } \\
\text { fenomena dalam LKPD }\end{array}$ & 35 & 28 \\
\hline 10 & Menyusun hipotesis bersama guru & 36 & 34 \\
\hline 11 & $\begin{array}{l}\text { Menjawab pertanyaan pada kolom komentar menggunakan } \\
\text { sumber informasi yang lain }\end{array}$ & 39 & 40 \\
\hline 12 & $\begin{array}{l}\text { Peserta didik menyusun kesimpulan bersama guru dalam } \\
\text { kolom komentar }\end{array}$ & 45 & 43 \\
\hline
\end{tabular}

Berdasarkan tabel 5. dapat dilihat waktu yang dibutuhkan masing-masing proses yang digunakan untuk model inkuiri terbimbing pada google classroom dalam dua pertemuan. Aktivitas yang dilakukan selama dua pertemuan memerlukan sebanyak 45 menit pada pertemuan pertama dan 43 menit pada pertemuan kedua. Pada aktivitas menuliskan nama dan nomor absen ketika akan menjawab pertanyaan termasuk aktivitas yang membutuhkan waktu yang paling lama yaitu dengan rentang 10 menit pada pertemuan pertama dan 9 menit pada pertemuan kedua. Hal ini menandakan bahwa kegiatan yang tidak relevan sangat minim terjadi pada dua kali pertemuan. Menurut Supardi (2013) pembelajaran efektif terjadi ketika perilaku peserta didik dapat diarahkan ke hal yang positif sehingga pembelajaran dapat berjalan dengan baik sesuai tujuan yang sudah dirancang (Hariani, 2020). Hal ini sesuai dengan model inkuiri terbimbing dalam membuat aktif beserta didik untuk lebih mengungkapkan kemampuan berpikir dan berperilaku positif secara ilmiah dalam keterampilan proses sains.

LKPD yang diberikan di dalamnya terdapat fenomena-fenomena untuk merumuskan hipotesis awal dan jawaban-jawaban yang disediakan sesuai dengan penelitian (Sheeba, 2013). Merumuskan hipotesis merupakan langkah-langkah untuk membantu mengembangkan keterampilan proses sains, hal ini ditunjukkan oleh Özgelen (2012) bahwa indikator soal-soal yang ditujukan dapat dijawab untuk menganilisa hipotesis.

Fenomena yang ditujukan pada LKPD bertujuan untuk menentukan variabel-variabel yang ada, hal ini juga dikemukakan oleh Komikesari (2016) yang menyatakan dalam penelitiannya bahwa pemberian bantuan yang dilakukan di awal dapat mengalihkan tanggung jawab peserta didik untuk menyelesaikan permasalahan sendiri. Penyusunan kesimpulan di akhir pembelajaran dapat melatih keterampilan berpikir dan mengolah sebuah informasi peserta didik, sesuai dengan Ayd (2013) yang menyatakan bahwa menyimpulkan suatu hal dapat melatih keterampilan dan mengembangkan ke level yang lebih tinggi.

\section{Hasil Belajar Keterampilan Proses Sains}

Hasil belajar peserta didik diukur dengan instrumen lembar pretest dan postest berupa 10 soal pilihan ganda pada materi kesetimbangan kimia. Ketuntasan hasil belajar dapat dilihat pada gambar 1 berikut ini. 
1091 Implementasi Model Pembelajaran Inkuiri Terbimbing Berbasis Google Classroom Terhadap Keterampilan Proses Sains Peserta Didik pada Materi Kesetimbangan Kimia - Nurul Hikmatun Uliya, Muchlis

DOI: https://doi.org/10.31004/edukatif.v4i1.2134

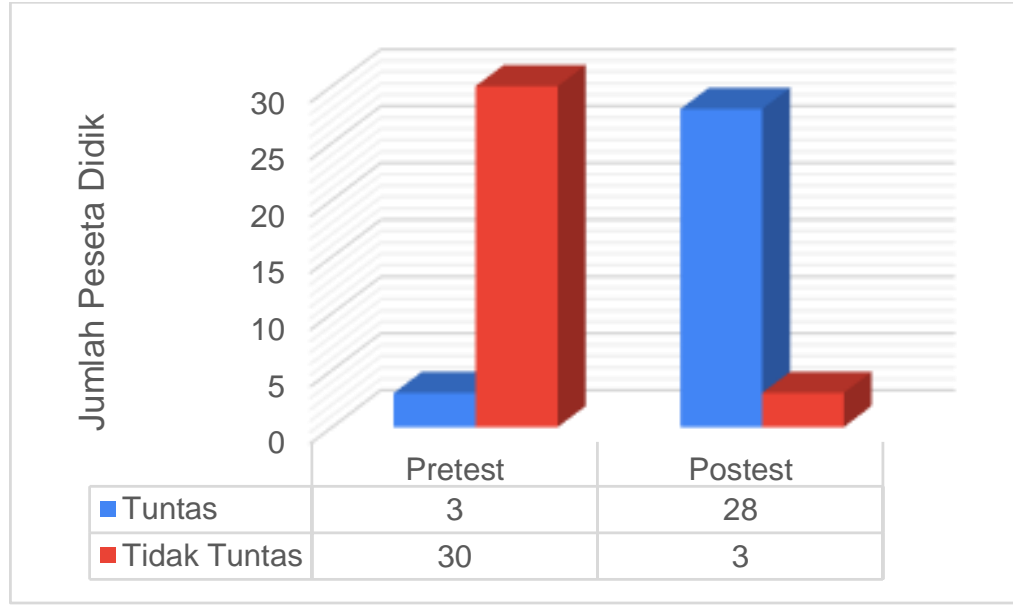

Gambar 1. Ketuntasan hasil belajar peserta didik

Berdasarkan Gambar 1. dapat dilihat bahwa hasil belajar peserta didik sebanyak 33 orang dari 34 orang mengikuti pretest, didapatkan sebanyak $88,24 \%$ peserta didik yang tidak tuntas dikarenakan nilai yang diperoleh berada di bawah KKM yaitu $<70$. Sedangkan pada saat posttest diikuti oleh 31 orang dari 34 orang diakatakan tuntas di atas nilai KKM dengan ketuntasan klasikal sebesar 82,35\% serta terdapat 26 peserta didik mendapatkan nilai $\mathrm{N}$-gain dengan kategori tinggi, dan 5 peserta didik memperoleh $\mathrm{N}$-gain dengan kategori sedang.

Maka dari itu dapat dikatakan bahwa model pembelajaran inkuiri terbimbing berbasis google classroom bisa dikatakan efektif untuk melatihkan keterampilan proses sains peserta didik. Hal ini diperkuat melalui hasil dari kenaikan hasil belajar didik dari sebelum diterapkannya inkuri terbimbing ke setelah diterapkannya inkuiri terbimbing dengan ketuntasan klasikal yang didapatkan mencapai 82,35\% dan peserta didik mampu mencapai N-gain tinggi dan sedang. Hasil yang sama didapatkan oleh Rizal (2014) yang menunjukkan bahwa inkuiri terbimbing bisa mengembangkan keterampilan proses sains. Didukung dengan penelitian yang dilaksanakan oleh Fahrudin (2014) yang memiliki judul"Implementasi Model Guided Inquiry Untuk Meningkatkan Keterampilan Proses Sains Pada Materi Kalo dan Perpindahannya" menyatakan bahwa terdapat kenaikan setiap aspek yang diteliti setelah diterapkannya inkuiri terbimbing. Selain itu, Daud (2018) juga juga menunjukkan kenaikan setiap aspek yang telah diterapkan model inkuiri terbimbing dengan judul penelitian "Efektivitas Pembelajaran Keterampilan Proses Sains (KPS) Pada Pokok Bahasan Termo Kimia Dalam Meningkatkan Kemampuan Peserta didik Di SMA Negeri 1 Krueng Barona Jaya Kabupaten Aceh Besar Dinas Pendidikan Aceh Ketuntasan". Pengungkapan peningkatan kemampuan keterampilan proses sains juga dikemukakan oleh Weil \& Joyce (2000) yang mengemukakan bahwa keterampilan proses sains dapat mengembangkan dalam merumuskan hipotesis, menentukan variabel, merumuskan masalah dan menyimpulkan.

\section{KESIMPULAN}

Berdasrkan hasil penelitian yang telah dipaparkan dari pendahuluan, metode penelitian, dan hasil dan pembahasan dapat ditarik kesimpulan bahwa aktivitas peserta didik saat pembelajaran di dalam google classroom berlangsung membutuhkan waktu yang cukup efektif dengan memperluas kegiatan yang relevan. Ketuntasan hasil belajar model inkuiri terbimbing berbasis google classroom mengalami kenaikan setelah diterapkannya inkuiri terbimbing dengan ketuntasan klasikal 82,35\% serta nilai $\mathrm{N}$-gain untuk 26 peserta didik mencapai katergori tinggi dan 5 peserta didik mencapai kategori sedang. Berdasarkan hasil di atas, dapat diperoleh kesimpulan umum bahwa penerapan model inkuiri terbimbing berbasis google classroom dapat 
1092 Implementasi Model Pembelajaran Inkuiri Terbimbing Berbasis Google Classroom Terhadap Keterampilan Proses Sains Peserta Didik pada Materi Kesetimbangan Kimia - Nurul Hikmatun Uliya, Muchlis

DOI: https://doi.org/10.31004/edukatif.v4i1.2134

melatihkan keterampilan proses sains peserta didik pada materi kesetimbangan kimia yang dibuktikan dengan aktivitas peserta didik dan ketuntasan hasil belajar keterampilan proses sains peserta didik.

\section{DAFTAR PUSTAKA}

Ambarsari, W., Santosa, S., \& Maridi. (2013). Penerapan Pembelajaran Inkuiri TerbimbingTerhadap Keterampilan Proses Sains Dasar Pada Pelajaran Biologi Peserta didik Kelas VIII SMP Negeri 7 Surakarta. Jurnal Pendidikan Biologi, 5, 81-95.

Amnie, E., Abdurrahman, A., \& Ertikanto, C. (2014). Pengaruh Keterampilan Proses Sains Terhadap Penguasaan Konsep Siswa Pada Ranah Kognitif. Jurnal Pembelajaran Fisika Universitas Lampung, 2(7), 117979.

Atikah, R., Prihatin, R. T., Hernayanti, H., \& Misbah, J. (2021). Pemanfaatan Google Classroom Sebagai Media Pembelajaran Di Masa Pandemi Covid-19. Jurnal Petik, 7(1), 7-18.

Ayd, A. (2013). Representation of Science Process Skills in The Chemistry Curricula For Grades 10, 11 and 12 / Turkey. International Journal of Education and Practice, 1(5), 51-63.

Daud, M. (2018). Efektivitas Pembelajaran Keterampilan Proses Sains (KPS) Pada Pokok Bahasan Termo Kimia Dalam Meningkatkan Kemampuan Siswa Di SMA Negeri 1 Krueng Barona Jaya Kabupaten Aceh Besar Dinas Pendidikan Aceh. Lantanida Journal, 6(1), 90.

Dewi, L. J. E. (2009). Pengembangan Media Pembelajaran Reaksi Kesetimbangan Kimia. Jurnal Pendidikan Teknologi Dan Kejuruan, 6(2), 71-80.

Diara, Fadiawati, N., \& Tania, L. (2017). Keterampilan Proses Sains Siswa pada Pembelajaran HukumHukum Dasar Kimia Berdasarkan Kemampuan Kognitif. Jurnal Pendidikan Dan Pembelajran Kimia, $6(1), 38-50$.

Fahrudin, M. F. N., Subekti, H., \& Anggaryani, M. (2014). Implementasi Model ADDIE. Jurnal Pendidikan Sains E-Pensa, 2(2), 378-383.

Hammi, Z. (2017). Implementasi Google Classroom Pada Kelas Xi Ipa Man 2 Kudus. Skripsi, 1-58.

Hariandja, M. T. (2009). Manajemen Sumber Daya Manusia Pengadaan, Pengembangan, Pengkompensasian, dan Peningkatan Produktivitas Pegawai. PT. Gramedia Widiasarna Indonesia.

Hariani, S. T. (2020). Efektivitas Pembelajaran Daring Menggunakan Google Classroom di MTS YAPI. Univeristas Islam Indonesia.

Hidayati, N., \& Yonata, B. (2019). Penerapan Model Pembelajaran Inkuiri Terbimbing Untuk Melatihkan Keterampilan Proses Sains Peserta Didik Pada Materi Kesetimbangan Kimia Kelas XI SMAN Ngoro Jombang. Unesa Journal of Chemical Education, 8(2), 148-155.

Indriani, A., Suryadharma, I. B., \& Yahmin. (2017). Identifikasi Kesulitan Peserta Didik Dalam Memahami Kesetimbangan Kimia. J-PEK (Jurnal Pembelajaran Kimia), 2(1), 9-13.

Komikesari, H. (2016). Peningkatan Keterampilan Proses Sains dan Hasil Belajar Fisika Siswa pada Model Pembelajaran Kooperatif Tipe Student Team Achievement Division. Tadris: Jurnal Keguruan Dan Ilmu Tarbiyah, 1(1), 15-22.

Mahdian, Almubarak, \& Hikmah, N. (2019). Implementasi Model Pembelajaran Icare (Introduction-ConnectApply-Reflect-Extend) Terhadap Keterampilan Proses Sains Pada Materi Larutan Elektrolit Dan Non Elektrolit. Jurnal Penelitian Pendidikan IPA, 5(1).

Meltzer, D. E. (2002). The Relationship Between Mathematics Preparation and Conceptual Learning Gains in Physics: A Possible "Hidden Variable" in Diagnostic Pretest Scores. American Journal of Physics, 70(12), 1259-1268.

Mulyana, S., Rusdi, R., \& Vivanti, D. (2018). The Effect of Guided Inquiry Learning Model and Scientific 
1093 Implementasi Model Pembelajaran Inkuiri Terbimbing Berbasis Google Classroom Terhadap Keterampilan Proses Sains Peserta Didik pada Materi Kesetimbangan Kimia - Nurul Hikmatun Uliya, Muchlis

DOI: https://doi.org/10.31004/edukatif.v4i1.2134

Performance on Student Learning Outcomes. Indonesian Journal of Science and Education, 2(1), 105.

Nafsi, L. L., \& Trisnawati, N. (2022). Efektivitas Penggunaan Google Classroom sebagai Media Pembelajaran Mata Kuliah Aplikasi Komputer Mahasiswa Pendidikan Administrasi Perkantoran. EDUKATIF : JURNAL ILMU PENDIDIKAN, 4(1), 38-52.

Nurliani, Sartika, R. P., \& Hadi, L. (2018). Deskripsi Keterampilan Proses Sains Siswa Kelas Xi Ipa Sma Negeri 2 Sungai Raya Pada Materi Asam Basa. Jurnal Pendidikan Dan Pembelajaran Khatulistiwa, 7(7), 1-13.

Özgelen, S. (2012). Students' science process skills within a cognitive domain framework. Eurasia Journal of Mathematics, Science and Technology Education, 8(4), 283-292.

Pendy, A., Suryani, L., \& Mbagho, H. M. (2022). Analisis Keefektifan Pembelajaran Online di Masa Pandemi Covid-19 pada Mahasiswa Pendidikan Matematika. EDUKATIF : JURNAL ILMU PENDIDIKAN, 4(1), $19-27$.

Rahmasiwi, A., Santosari, S., \& Sari, D. P. (2015). Peningkatan Keterampilan Proses Sains Siswa dalam Pembelajaran Biologi Melalui Penerapan Model Pembelajaran Inkuiri di kelas XI MIA 9 (ICT) SMA Negeri 1 Karanganyar Tahun Pelajaran 2014/2015. Seminar Nasional XII Pendidikan Biologi FKIP UNS 2015, 9(2013), 428-433.

Rakim, Wilonoyudho, S., \& Wijanarko, D. (2017). Penerapan Model Pembelajaran Shesil (Soft, Hard and Environment Skill Integrated Learning) pada Kecakapan Otomotif. Journal of Vocational and Career Education, 2(72).

Riduwan. (2015). Dasar-Dasar Statistika. Bandung : Alfabeta.

Ristiyani, E., \& Bahriah, E. S. (2016). Analisis Kesulitan Belajar Kimia Siswa Di Sman X Kota Tangerang Selatan. Jurnal Penelitian Dan Pembelajaran IPA, 2(1), 18. https://doi.org/10.30870/jppi.v2i1.431

Rizal, M. (2014). Pengaruh pembelajaran inkuiri terbimbing dengan mind map terhadap keterampilan proses sains dan hasil belajar IPA. Jurnal Pendidikan Sains, 2(4), 159-165.

Sabran, \& Sabara, E. (2019). Keefektifan Google Classroom Sebagai Media Pembelajaran. Prosiding Seminar Nasional Lembaga Penelitian Universitas Negeri Makasar, 122-125.

Seliwati, Sidaruk, S., \& Damsyik, A. (2020). Kesulitan Memahami Faktor-Faktor Yang Mempengaruhi Kesetimbangan Kimia Pada Siswa SMA Negeri Di Kota Palangka Raya. Jurnal Ilmiah Kanderang Tingang, 11(2), 315-327.

Sheeba, M. N. (2013). An Anatomy of Science Process Skills in The Light of The Challenges to Realize Science Instruction Leading to Global Excellence in Education. Educationa Confab, 2(4), 108-123.

Weil, M., \& Joyce, B. R. (2000). Models of Teaching (6th ed.). Boston : Allyn and Bacon. 